Bryn Mawr College

Scholarship, Research, and Creative Work at Bryn Mawr College

Greek, Latin, and Classical Studies Faculty Research

and Scholarship

Greek, Latin, and Classical Studies

1978

\title{
A New Interpretation of the Anavysos Chous
}

Richard Hamilton

Bryn Mawr College, rhamilto@brynmawr.edu

Let us know how access to this document benefits you.

Follow this and additional works at: http://repository.brynmawr.edu/classics_pubs

Part of the Classics Commons

\section{Custom Citation}

Hamilton, Richard. "A New Interpretation of the Anavysos Chous." American Journal of Archaeology 82 (1978): 385-387.

This paper is posted at Scholarship, Research, and Creative Work at Bryn Mawr College. http://repository.brynmawr.edu/classics_pubs/28

For more information, please contact repository@brynmawr.edu. 


\section{Archaeological Notes}

\section{A NEW INTERPRETATION OF THE ANAVYSOS CHOUS}

The Anavysos chous ${ }^{1}$ is our only pictorial evidence for a fifth century raised stage in Athens as well as being our only representation of fifth century actors in the presence of an audience and, in the opinion of some scholars, of a fifth century stage curtain. ${ }^{2}$ It de- picts two spectators seated on klismoi watching an actor dressed as Perseus dancing on a low stage partly concealed by something with curving lines. ${ }^{3}$ The identification of the actor as Perseus is assured by the sickle and the pouch. Virtually everything else is variously interpreted. The performance is said to be a comedy or a pantomime; the occasion public or private; the actor a dwarf or not. ${ }^{4}$ The curving lines

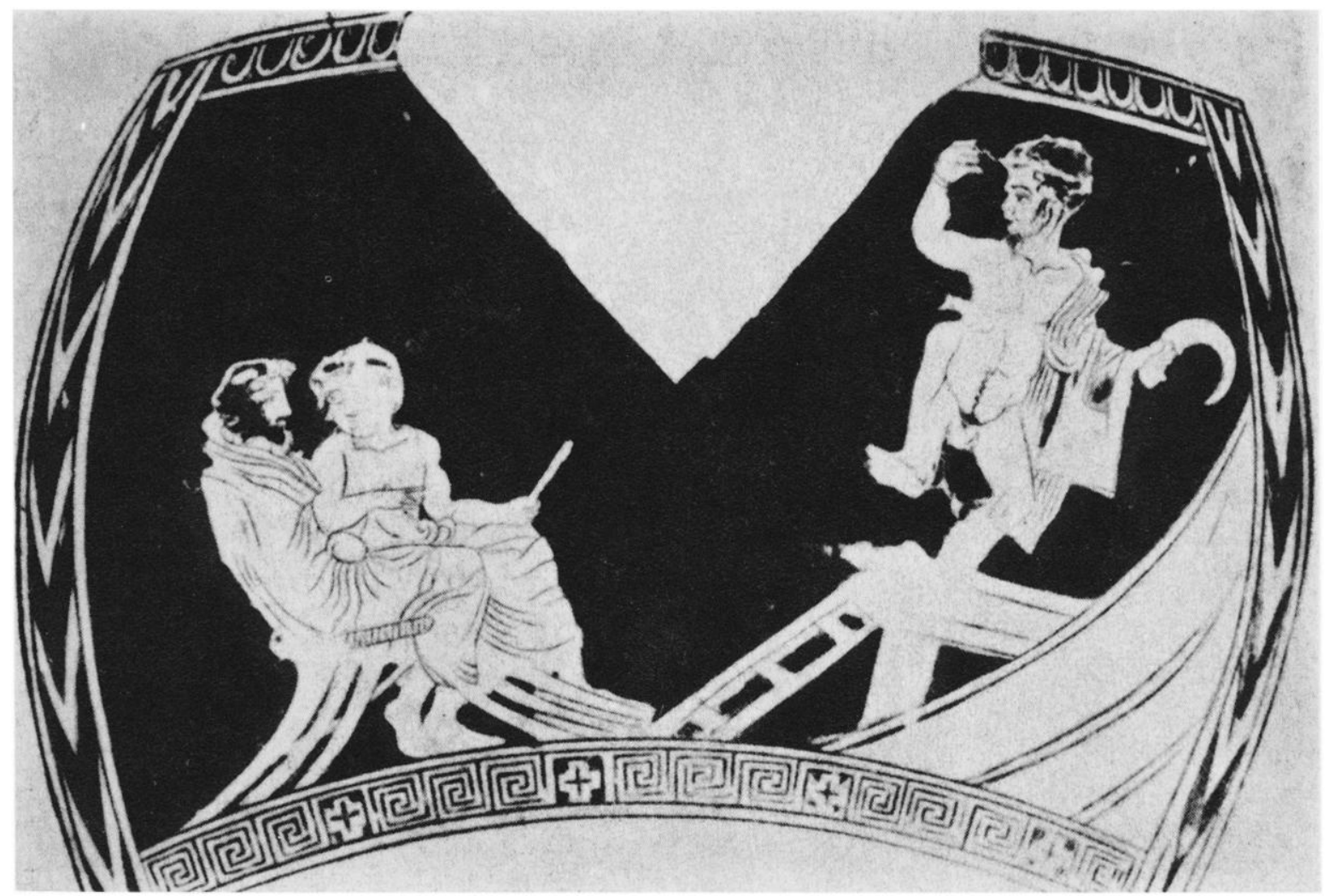

Fig. I. Anavysos chous, Gillieron drawing (from $A R V^{2}$ 1215, I)

${ }^{1}$ J.D. Beazley, $A R V^{2}$, 1215, I (= our fig. I). See also A.W. Pickard-Cambridge, The Dramatic Festivals of Athens ${ }^{2}$ (Oxford 1968), hereafter $D F A^{2}$, fig. 76 .

2 "The only surviving picture of audience and actor in Attic comedy" T.B.L. Webster, Greek Theatre Production ${ }^{2}$ (London 1970) 7; "the only picture of the fifth-century stage . . the only picture of the fifth-century curtain," Webster 20. See also P. Arnott, Greek Scenic Conventions (Oxford 1962) I6 and C.W. Dearden, The Stage of Aristophanes (London 1976) 13. G. Caputo, "Palcoscenico su Vaso Attico," Dioniso 4 (I935) 277, compared a krater of slightly earlier date $\left(A R V^{2}\right.$ I053, 39) which shows a satyr in tights (i.e. an actor dressed as a satyr) "che danza su podio a pedana semplice." I do not think the two "stages" are at all comparable, but I am sur- prised that this second example of a "stage" has not been discussed.

${ }^{3}$ Caputo (supra n. 2) 274, identified the chairs with the marble prohedriai that still remain in the theater of Dionysus in Athens, but there is nothing to distinguish them from "The Easy Chair with Back" catalogued by G.M.A. Richter in The Furniture of the Greeks, Etruscans and Romans (London I966) 33 .

${ }^{4}$ Comedy: Caputo (supra n. 2) 274; S.P. Karouzou, "Vases from Odos Pandrosou," JHS 65 (1945) 42; T.B.L. Webster, "South Italian Vases and Attic Drama," $C Q \quad 42$ (1948) I9; $D F A^{2}$ 2I I. Pantomime: O. Weinreich Epigrammstudien I: Epigramm und Pantomimus (Heidelberg 1948) I27; L. Breitholtz, Die dorische Farce (Stockholm 1960) 197; Beazley 
have been called a siparium (curtain), background drapery wrongly placed by the painter and a decorative hanging in the parodos. ${ }^{5}$ The spectators are variously labeled as poet and choregos, poet and producer, patron and beloved, priest of Dionysus and producer or simply two spectators pars pro toto. ${ }^{6}$

The most immediate problem, I think, is the identification of the curving lines to the right of and partly concealing the stage. These are universally interpreted as drapery of some sort: "it is difficult to explain them otherwise." 7 Yet the material looks too rigid to be drapery and it is fastened to no visible support. As Webster admitted, "its shape and form are extremely difficult to explain." At first he compared it to the fabric often hung from the posts supporting the stage in the so-called Phlyax vases. ${ }^{9}$ Then he found an obscure statement in Aristotle's Nicomachean Ethics (I 232323 ) saying that the vulgar man producing a comedy introduces purple (cloth) in the parodos. ${ }^{10}$ The scholia note that normally skins were used as parapetasmata (hangings), and Webster concluded that "some sort of hanging is required in the parodos." 11 He later modified this: "probably the parodos means here the way up to the central door, the background"12 and so "the curved lines at the

(supra n. I) 1215; A.D. Trendall, Phlyax Vases $^{2}$ (London 1967) 20. Arnott (supra n. 2) I6 and M. Bieber, The History of the Greek and Roman Theater ${ }^{2}$ (Princeton 1961) 48, call the production a farce. Public: Webster I9; Dearden (supra n. 2) 13. Private: H. Bulle, Das Theater zu Sparta, SBBayer 1937.2, 52; A.W. Pickard-Cambridge, The Theatre of Dionysus in Athens (Oxford 1946) 74; Weinreich 127. Arnott and Karouzou call it a rehearsal. Dwarf: Pickard-Cambridge; G. van Hoorn, Choes and Anthesteria (Leiden 1951) 37; Beazley. Not dwarf: T.B.L. Webster, "Attic Comic Costume: a Reexamination," ArchEph 1953-1954, vol. 2 (hereafter Webster ArchEph) 200; Breitholtz 196.

5 Caputo, (supra n. 2) 278 , identified the lines as the sipari$u m$ or aulaia, the curtain drawn in front of the Roman stage, but it is universally agreed that this is much too early for such a curtain. Bulle, (supra n. 4) 5I, thought the painter intended to indicate background drapery. Webster's changing views are catalogued below.

${ }^{6}$ Poet and choregos: Webster, ArchEph 200; H. Baldry, The Greek Tragic Theatre (London 1971) 45. Poet and producer; Arnott (supra n. 2) 16, Karouzou (supra n. 4) 42. Patron and beloved: Bulle (supra n. 4) 52; Weinreich (supra n. 4) 126. Priest and producer: Caputo (supra n. 2) 275. Two spectators: Beazley (supra n. I) I215; Trendall (supra n. 4) 20; $D F A^{2}$ 2I I; Bieber (supra n. 4) 48; Baldry.

7 T.B.L. Webster, "Menander: Production and Imagination," Bulletin of the John Rylands Library 45 (1962-1963) 262.

${ }^{8}$ Webster (supra n. 4) I 9.

${ }^{9}$ Webster (supra n. 4) I9. For illustrations see Bieber (supra n. 4) fig. 483, 485, 491; 492, 498, 507, 51 I, 518, 535. But this drapery is always clearly attached to the stage, like festoons.

10 Webster, ArchEph 200.

11 Webster, ArchEph 200.

12 Webster (supra n. 7) 262.

13 A.D. Trendall and T.B.L. Webster, Illustrations of Greek side of the stage may represent a curtain, which decorates the background on either side of the stagedoor." 13 However there is no evidence that parodos could ever mean skene, and Aristotle may simply be talking of dressing the chorus in purple. ${ }^{14}$ Webster himself offered a less specific interpretation a few years ago: "the curtain is by the side of the stage so that it isolates the area in which the comic Perseus dances." ${ }^{15}$

A quite different possibility is that the parallel curved lines represent the curved stern of a boat. ${ }^{16}$ The picture then could represent the Dionysiac carrus navalis found on a number of vases. ${ }^{17}$ The bearded spectator "wrapped in his mantle, wreathed" 18 bears a striking resemblance to the Dionysus seated in one of the "floats." 19 The grape vine has vanished and the flute players have been replaced by our dancing Perseus, but Dionysus's ivy crown remains. ${ }^{20}$ The shape of the pot suggests that it is appropriate for the Anthesteria and perhaps our dancing Perseus is to be explained as one of the comic actors who were said to compete for a place in the City Dionysia during the Anthesteria. ${ }^{21}$ The second spectator, holding a staff, remains a mystery. ${ }^{22}$

\section{Drama (London 1971) i17.}

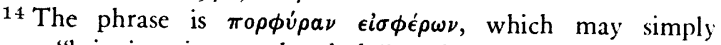
mean "bringing in purple cloth." Aristotle goes on to say "just as in Megara," which is more likely to refer to clothing than scenic design (over which a choregos may have had less say in any case). I am also suspicious of scholia that speak of "hides" being used as hangings-it sounds antiquarianand wonder if contemporary practice (i.e. the siparium) is not being invoked to solve an aporia.

15 Webster (supra n. 2) 20.

${ }^{16}$ See for example L. Casson, Ships and Seamanship in the Ancient World (Princeton 1971), fig. 81, 84, 85, 88; J.S. Morrison and R.T. Williams, Greek Oared Ships 90o-322 B.C. (Cambridge I968) fig. 9c, IId, I2f, I4g, 2Ie; and L. Deubner, Attische Feste ${ }^{3}$ (Darmstadt 1969) fig. I 2.I.

${ }^{17}$ These were first collected by A. Frickenhaus, "Der Schiffskarren des Dionysos in Athen," IdI 27 (1912) table I. See also $D F A^{2}$ fig. I I-I3.

18 Karouzou (supra n. 4) 42.

19 An Attic skyphos in Bologna (DFA $A^{2}$ fig. II; Frickenhaus [supra n. I7] table I fig. III; Deubner [supra n. I6] fig. II.I; C.H.E. Haspels, Attic Black-figured Lekythoi [Paris 1936] 253, 15). Professor G. Pinney has pointed out to me the similarity, especially in drapery, to the cult statue on a column krater in Basel, identified as Dionysus Eleuthereus by M. Schmidt, "Dionysien," AntK Io (1967) 76 (supra fig. 1o on p. 380 [ed.]).

20 Caputo (supra n. 2) 274; Bulle (supra n. 4) 52.

21 The evidence for these chutrinoi agōnes is slender (see $D F A^{2}$ 15-16). By their name they should fall on the third day of the Anthesteria (or the evening of the second, see $D F A^{2}$ Io n.8) and so a representation of them on the boat bringing Dionysus, necessarily before the hieros gamos of the second day, may seem unlikely.

22 If he were bearded we would identify him as the judge often seen in vases depicting competition scenes. Beardless 
It must be admitted that there are difficulties with such an interpretation. First, Dionysus is facing not the prow but the stern, which itself lacks the usual double, swan-headed aphlaston. ${ }^{23}$ Secondly, he is holding none of the usual implements: cantharus, thyrsus or grape vine. Finally, there is no firm evidence connecting the carrus navalis with the Anthesteria. ${ }^{24}$

The greatest problem is the poor condition of the chous itself, to judge from the pictures in Caputo, Webster and Brommer. ${ }^{2 \pi}$ Since it is at present impossible to examine the original or obtain new photographs, one must rely on the drawing of E. Gilliéron (here fig. I) and the description of Caputo. Still, I think the problem of the parallel curved lines should be raised. If it is a boat and if the bearded spectator is Dionysus, we lose our evidence for a fifth century raised stage but we gain a piece of evidence that may link the carrus navalis with the Anthesteria. ${ }^{26}$ And if Perseus is a comic actor, as the tights suggest, ${ }^{27}$ we have our first manifestation of the shadowy chutrinoi agōnes. ${ }^{28}$

DEPARTMENT OF GREEK

Richard Hamilton

BRYN MAWR COLLEGE

BRYN MAWR, PENNSYLVANIA IgOIO

\section{TWO COMPOSITIONAL TENDENCIES IN AMARNA RELIEF*}

It is widely believed that the art of Amarna did not

judges (and trainers), however, are not unknown: see E.N. Gardiner, Greek Athletic Sports and Festivals (London 1910) figs. $38,48,54,66,79,82,114,115$, and perhaps 116 . Figure 38, a Panathenaic amphora in the British Museum ( $C V A A_{I}$ III $\mathrm{H}$ e pl. $4,3 \mathrm{~b}$ ), shows a victor being crowned by a judge closely resembling our mystery figure: beardless, seated, with bare torso.

${ }^{23}$ See Frickenhaus (supra n. 17) 63. However, one of his three ships clearly does not have a swan's head. Presumably the basketlike contraption seen hanging to the left or right of the sterns of his ships would not be visible on ours.

${ }^{24}$ Nor is any of the three vases showing it of the appropriate shape. Still, most recent statements favor the connection, e.g. $D F A^{2}$ I 2 n.2; G.M. Sifakis, Studies in the History of Hellenistic Drama (London 1967) io but not W. Burkert, Homo Necans (Berlin 1972) 223-24.

${ }^{25}$ Caputo (supra n. 2) fig. I-4; Webster, ArchEph fig. 4; F. Brommer, Satyrspiele (Berlin 1944) fig. 17-19.

${ }^{26}$ One must be cautious in view of the strong negative conclusion of A. Rumpf, "Attische Feste-Attische Vasen," Bonnjbb 161 (1961) 212: "es dürfte aber auch endlich einmal an der Zeit sein, zu fragen, ob und wieweit der Zeugniswert der oft angeführten Kannen und Kännchen als 'Choen-Kannen' für die Rekonstruktion des Choen-Festes berechtigt ist. Die Darstellungen auf den Kannen sprechen nicht dafür." This may be excessive: "so schüttet er das Kind mit dem Bade oder besser das Kinderfest mit den Choen aus," E. Simon, "Ein Anthesterien-Skyphos des Polygnotos," AntK 6 (1963) 8 n.io. See also Schmidt (supra n. 19) 78 .

$2 \pi$ The tights seem clear from the two lines around Perseus's right hand. I cannot see the "twisted-up phallos" mentioned constitute an overwhelming revision of tradition. For our purposes, it is therefore necessary to fix upon a precise formulation of this "tradition" of which Amarna art was supposedly but an extension or exaggeration.

It seems that almost all of the important compositional laws were laid down in the Egyptian Old Kingdom and were maintained, with few contrary interludes, into the Hellenistic era. One scholar has remarked that the reliefs of the Fifth Dynasty might be called "classical" Egyptian art. ${ }^{1}$ These reliefs present us with some of the best examples of Egyptian relief art, and clearly exhibit the tendencies and techniques of the genre at its height. On the other hand, those who hold that Amarna relief was an extension of tradition mean to refer in particular to the tradition of the Eighteenth Dynasty. The innovations of Amarna art, including many of the well-known stylistic exaggerations, were a manifestation of a general disintegration of cultural formality characteristic, it is believed, of the entire Eighteenth Dynasty. I shall not consider developments preparatory to the reforms of the Amarna period, but I do believe that gradual changes in artistic method and a general broadening of world-view during the early New Kingdom had a significant effect upon Amarna art. Yet despite this, there were specific changes in art which can be dated only to the Amarna years, including changes in the composition of relief representations. ${ }^{2}$ With

in $D F A^{2} 21 \mathrm{I}$, following Webster, ArchEph 200.

28 If not, then perhaps we have a representation of the "dances in costume" that shocked Apollonius ( I would like to thank Professors M.L. Lang, G. Pinney and E. Simon for reading this paper and offering very helpful suggestions and the Journal's referee for catching two egregious blunders. I am also indebted to two students, Monica Barran and Raymond Liddell, for asking the right questions.

* I am grateful to the Metropolitan Museum of Art for supplying me with information on Amarna reliefs in the MMA collection, to the Egypt Exploration Socicty for assisting me in queries regarding Flinders Petrie's notes and records of his excavations at Tell el Amarna in 1892, and to Dr. M.A.S. Cameron of the University of Western Ontario, Prof. W.K. Simpson of Yale University and the Boston Museum of Fine Arts, the editor of $A J A$, and Mr. Peter Sidman, for comments and criticism on earlier drafts of this paper. I am especially grateful to Prof. Dr. Jürgen Settgast, Director of the Ägyptisches Museum, West Berlin, for kind permission to reproduce the relief in his museum's collection.

${ }^{1}$ H.T. Mohr, The Mastaba of Hetep-her-akhti, Ex Oriente Lux 5 (Leiden 1943) 3. For traditional relief composition, see H.A. Groenewegen-Frankfort, Arrest and Movement (London 1951) I14-4I, W.S. Smith, Interconnections in the Ancient Near East (New Haven 1969) 137-47, 168-79, and F. Matz, "Zur Komposition ägyptischer Wandbilder," $J d I 37$ (1924) 39-53.

${ }^{2}$ For composition in the Amarna period, see C.F. Nims, "The transition from the traditional to the new style of wall relief under Amenhotep IV," JNES 32 (1973) I8I-87; C.R. 